\title{
PENGARUH CORPORATE SOCIAL RESPONSIBILITY, KEPUASAN NASABAH, CITRA PERUSAHAAN, DAN EKUITAS MEREK TERHADAP PREFERENSI MEREK BANK BPD BALI
}

\author{
I Wayan Ariwangsa ${ }^{1}$, Luh Putu Mahyuni² \\ ${ }^{1}$ Jurusan Manajemen, Universitas Pendidikan Nasional \\ Email: harivamsa_oke@yahoo.co.id \\ ${ }^{2}$ Jurusan Akuntansi, Universitas Pendidikan Nasional \\ Email: lpmahyuni@gmail.com
}

Masuk : 01-06-2019, revisi: 14-10-2019, diterima untuk diterbitkan : 30-10-2019

\begin{abstract}
ABSTRAK
Penelitian ini bertujuan untuk menawarkan dan menguji secara empiris model yang menjelaskan hubungan antara corporate social responsibility (CSR), kepuasan nasabah, citra perusahaan, ekuitas merek, dan tingkat preferensi merek bank. Data dikumpulkan melalui kuesioner dengan metode accidental sampling. Data dari 100 responden kemudian dianalisis dengan structural equation modelling (SEM) untuk menguji hipotesis. Penelitian ini mengindikasikan bahwa CSR, kepuasan nasabah, citra perusahaan dan ekuitas merek mampu menjelaskan sebanyak 83,5\% dari variasi preferensi merek. Model penelitian ini juga telah memenuhi seluruh kriteria goodness of fit index sebagai model yang baik. Penelitian ini memberikan bukti empiris bahwa praktik CSR yang baik memberikan pengaruh positif bagi upaya peningkatan kepuasan nasabah, citra perusahaan, ekuitas merek, dan preferensi merek bank. Sosialisasi atas praktik CSR dengan cara yang tepat dan melalui media yang tepat akan dapat mengoptimalkan manfaat CSR bagi upaya peningkatan reputasi bank dan preferensi merek bank. Penelitian ini juga memberikan bukti empiris akan adanya pengaruh positif signifikan antara kepuasan nasabah dan citra perusahaan, kepuasan nasabah dan preferensi merek, citra perusahaan dengan ekuitas merek, citra perusahaan dengan preferensi merek, dan pengaruh positif signifikan antara ekuitas merek dengan preferensi merek. Penelitian berikutnya dapat dilakukan dengan menggunakan sampel beberapa bank untuk dapat menguji lebih jauh kehandalan model yang ditawarkan dalam penelitian ini.
\end{abstract}

Kata Kunci: Corporate Social Responsibility (CSR), kepuasan nasabah, citra perusahaan, ekuitas merek, preferensi merek

\begin{abstract}
This study aims at offering and empirically testing a model explaining relationships between corporate social responsibility (CSR), customer's satisfaction, brand image, brand equity, and brand preference. Data was collected using questionnaire. As many as 100 datasets were analysed using structural equation modelling (SEM) to test the hypotheses. This study indicates that CSR, customer's satisfaction, brand image, and brand equity could explain 83,5\% of the variation of brand preference. The model of this study has met all criteria of goodness of fit index as a good model. This study provides empirical evidence of the benefits of CSR in increasing customer's satisfaction, brand image, brand equity, and brand preference. Disclosure of CSR practices using proper approach and right channels will optimalize the benefits of CSR in increasing bank reputation and brand preference. This study also provides empirical evidence of the significant positive influence of customer's satisfaction on brand image, customer's satisfaction on brand preference, brand image on brand equity, brand image on brand preference, and significant positive influence of brand equity on brand preference. Future research could further test the robustness of this model by using data collected from various banks.
\end{abstract}

Keywords: Corporate Social Responsibility (CSR), customer's satisfaction, corporate image, brand equity, brand preference 


\section{PENDAHULUAN}

\section{Latar Belakang Masalah}

Corporate Social Responsibility (CSR) menurut Bank Dunia adalah komitmen perusahaan untuk berperilaku etis dan memberikan kontribusi bagi pembangunan berkelanjutan melalui kerjasama dengan segenap pemangku kepentingan yang terkait untuk memperbaiki kehidupan mereka dengan cara-cara yang baik bagi kepentingan bisnis, agenda pembangunan berkelanjutan, dan masyarakat pada umumnya (Kiroyan, 2009). Melalui CSR, perusahaan tidak semata-mata memprioritaskan tujuannya pada memperoleh laba setinggi-tingginya melainkan juga memperhatikan/mempertimbangkan aspek ekonomi, sosial, dan aspek lingkungan (Suharto, 2009).

Cavusgil et al. (2014) menyatakan bahwa CSR adalah tentang menjalankan bisnis dengan caracara yang sesuai dengan ataupun melebihi harapan etika, hukum dan komersial dari pelanggan/konsumen, pemegang saham, karyawan, dan masyarakat sekitar lokasi bisnis. Sementara itu, konsep kesinambungan (sustainability) berarti memenuhi kebutuhan kemanusiaan tanpa membahayakan generasi mendatang. Menggabungkan etika, CSR dan kesinambungan (sustainability) ke dalam operasi global perusahaan adalah jalan menuju kesuksesan perusahaan dalam jangka panjang.

Para pelaku bisnis dan peneliti hingga kini berupaya untuk mengetahui bagaimana CSR dapat dimanfaatkan untuk meningkatkan kepuasan konsumen, citra perusahaan, ekuitas merek, dan preferensi merek. Beberapa penelitian yang telah dilakukan sebelumnya membuktikan bahwa CSR mampu meningkatkan kepuasan konsumen melalui praktik CSR penuh empati yang dirasakan langsung oleh konsumen (McWilliams et al., 2006; Athanassopoulos, 2000). CSR berupa bantuan sosial kepada masyarakat juga mampu meningkatkan citra perusahaan (Yenti, 2013; Husni Falah Wijaya, 2015). Penelitian oleh Handayani (2012) dan Ariningsih (2009) membuktikan bahwa ekuitas merek dapat ditingkatkan melalui praktik CSR yang diapresiasi masyarakat dan konsumen. Baskentli, Sen, Du dan Bhattacharya (2019) membuktikan bahwa CSR dapat meningkatkan preferensi merek suatu perusahaan. Penelitian ini dibangun dari penelitian-penelitian sebelumnya dan mengisi gap dalam literatur dengan menawarkan model kompleks yang menjelaskan dan membuktikan relasi beberapa variabel secara bersamaan untuk mendapatkan model yang lebih lengkap mengenai relasi CSR, kepuasan konsumen, citra perusahaan, ekuitas merek, dan preferensi merek. Mengingat masih relatif terbatasnya penelitian terkait CSR pada industri perbankan, penelitian ini menggunakan bank, khususnya Bank BPD Bali sebagai obyek penelitian.

\section{Rumusan Masalah}

Berikut adalah rumusan masalah penelitian ini:

1. Apakah program CSR berpengaruh terhadap kepuasan nasabah Bank BPD Bali?

2. Apakah program CSR berpengaruh terhadap citra perusahaan Bank BPD Bali?

3. Apakah program CSR berpengaruh terhadap ekuitas merek Bank BPD Bali?

4. Apakah program CSR berpengaruh terhadap preferensi merek Bank BPD Bali?

5. Apakah kepuasan nasabah berpengaruh terhadap citra perusahan Bank BPD Bali?

6. Apakah citra perusahaan berpengaruh terhadap ekuitas merek Bank BPD Bali?

7. Apakah kepuasan nasabah berpengaruh terhadap preferensi merek Bank BPD Bali?

8. Apakah citra perusahaan berpengaruh terhadap preferensi merek Bank BPD Bali?

9. Apakah ekuitas merek berpengaruh terhadap preferensi merek Bank BPD Bali? 


\section{Kajian Teori dan Perumusan Hipotesis}

Kepuasan pelanggan merupakan hal yang penting untuk dipertahankan oleh setiap perusahaan. Kepuasan pelanggan berkaitan langsung dengan nilai keberhasilan dari suatu produk dan pelayanan yang diberikan (Naik, C.N. Krishna., Gantasala, S.B., and Prabhakar, 2010). Kepuasan pelanggan sangat diperhatikan oleh perusahaan karena berdampak pada kinerja perusahaan dimana pelanggan yang puas akan melakukan pembelian ulang (Cronin, Joseph JR., Brady, Michael K., and Hult, 2000).

Nareeman dan Hassan (2013) mengungkapkan bahwa dampak CSR terhadap kepuasan pelanggan dan retensi menunjukkan bahwa CSR berpengaruh positif dan signifikan terhadap kepuasan dan loyalitas pelanggan. Kegiatan kedermawanan yang dilakukan oleh perusahaan dapat berpengaruh secara tidak langsung terhadap permintaan konsumen melalui tingkat kepuasan dan ingatan pelanggan yang tinggi terhadap suatu barang ataupun jasa. Dengan adanya CSR dalam sebuah perusahaan membuat perusahaan tersebut lebih memahami dan meningkatkan pengetahuan khusus terhadap pelanggannya, hal ini akan berdampak pada kepuasan pelanggan (McWilliams et al., 2006). Athanassopoulos (2000) mengatakan bahwa nilai CSR berdampak terhadap kepuasan pelanggan. Referensi atas penelitian-penelitian terdahulu mengarahkan pada hipotesis sebagai berikut:

\section{H1: CSR berpengaruh secara positif dan signifikan terhadap kepuasan nasabah Bank BPD} Bali.

Yulianita (2008) berpendapat bahwa kegiatan CSR dilakukan untuk dapat merespon keadaan sosial yang terjadi di lingkungan sekitar yang tidak hanya dinikmati atau dimanfaatkan oleh lingkungan sekitar yang menjadi sasaran saja tetapi juga perusahaan tersebut akan menerima manfaaat atas kegiatan yang mereka lakukan tersebut khususnya dalam penciptaan, peningkatan, dan pemeliharaan citra perusahaan di mata masyarakat. Berikut adalah hipotesis yang dirumuskan:

\section{H2: CSR berpengaruh secara positif dan signifikan terhadap citra perusahaan Bank BPD} Bali.

Kegiatan Corporate Social Responsibility yang dilaksanakan oleh suatu perusahaan dapat menimbulkan brand loyalty dimana brand loyalty merupakan indikator dari ekuitas merek, brand loyalty terbentuk dari kesan positif terhadap suatu produk yang menimbulkan ikatan emosional yang berkembang menjadi brand loyalty (Ariningsih, 2009). Berikut adalah hipotesis yang dirumuskan:

\section{H3: CSR berpengaruh secara positif dan signifikan terhadap ekuitas merek.}

Yenti (2013) meneliti pengaruh penerapan program corporate sosial responsibility terhadap preferensi merek perusahaan PT. Semen Padang berkesimpulan bahwa CSR berpengaruh signifikan terhadap preferensi merek perusahaan. Berikut adalah hipotesis yang dirumuskan:

H4: CSR berpengaruh secara positif dan signifikan terhadap tingkat preferensi merek Bank BPD Bali.

Kualitas suatu pelayanan memiliki peranan penting di dalam proses evaluasi karena kepuasan pelanggan dengan pengalaman layanan memperkuat perilaku seseorang melalui Word Of Mouth (WOM) untuk mempengaruhi citra suatu perusahaan (A. Mukherjee, 2003). Baik buruknya kualitas pelayanan tidak hanya berdasarkan persepsi penyedia pelayanan, tetapi berdasarkan persepsi nasabahnya. Persepsi terhadap kualitas pelayanan merupakan keyakinan nasabah akan pelayanan yang diterimanya secara menyeluruh (Shaikh et al., 2011). Berikut adalah hipotesis yang dirumuskan: 


\section{H5: Kepuasan nasabah berpengaruh secara positif dan signifikan terhadap citra perusahaan.}

Penelitian terdahulu menemukan bahwa terdapat hubungan antara citra perusahaan terhadap Ekuitas merek. Penelitian Handayani (2012) membuktikan bahwa brand equity dipengaruhi secara positif dan signifikan oleh corporate reputation dan social equity brand. Berikut adalah hipotesis yang dirumuskan:

\section{H6: Citra perusahaan berpengaruh secara positif dan signifikan terhadap ekuitas merek.}

Kepuasan pelanggan berhubungan erat dengan loyalitas pelanggan, dimana pelanggan yang terpuaskan akan menjadi pelanggan yang loyal, kemudian pelanggan yang loyal tersebut secara tidak langsung akan menjadi tenaga pemasaran bagi perusahaan tersebut yaitu dengan cara memberikan rekomendasi dan informasi positif kepada calon pelanggan lain (Mowen, J.C., and Minor, 1998). Kesetiaan pelanggan akan berpengaruh kepada pembelian berulang (repeat buying) dan rekomendasi (recommended buying). Jika konsumen merasa puas dengan merek tertentu dan melakukan pembelian secara berulang maka dapat dikatakan bahwa tingkat kesetiaan konsumen tersebut tinggi, sebaliknya jika konsumen tidak terlalu puas akan suatu merek tertentu dan cenderung membeli produk dengan merek yang berbeda-beda maka dapat dikatakan bahwa tingkat kesetiaan pelanggan terhadap produk tersebut rendah (Samuel \& Foedjiawati, 2005). Schiffman dan Kanuk (2004) menyatakan bahwa tingkat kepuasan konsumen akan mempengaruhi derajat loyalitas merek konsumen, karena salah satu faktor yang mempengaruhi loyalitas merek adalah kepuasan konsumen. Berikut adalah hipotesis yang dirumuskan:

H7: Kepuasan pelanggan berpengaruh secara positif dan signifikan terhadap preferensi merek.

Kegiatan CSR pada awalnya dilakukan sebagai bentuk kedermawanan perusahaan, namun dewasa ini telah berkembang menjadi sebuah strategi dalam meningkatkan citra perusahaan. Di dalam persaingan bisnis yang ketat ini, memiliki keunggulan kompetitif merupakan hal yang penting bagi perusahaan. Persaingan yang ketat tersebut menyebabkan perusahaan perlu melakukan upaya untuk meningkatkan reputasinya sebagai salah satu keunggulan daya saing, dan pada akhirnya bisa meningkatkan penjualan. Berikut adalah hipotesis yang dirumuskan:

H8: Citra perusahaan berpengaruh secara positif dan signifikan terhadap preferensi merek.

Ekuitas yang tinggi berhubungan dengan kepuasan pelanggan yang tinggi, preferensi merek, dan loyalitas. Beberapa penelitian menunjukkan terdapat hubungan positif antara ekuitas merek, preferensi merek, dan niat pembelian dengan efek moderasi biaya perpindahan yang mempengaruhi hubungan antara ekuitas merek dan niat beli. Ekuitas merek juga ditemukan berpengaruh secara positif dan signifikan terhadap preferensi merek. Semakin kuat ekuitas merek suatu produk, semakin kuat daya tariknya di mata konsumen untuk termotivasi memilih produk tersebut. Berikut adalah hipotesis yang dirumuskan:

H9: Ekuitas merek berbengaruh secara positif dan signifikan terhadap preferensi merek.

\section{METODE PENELITIAN}

Untuk menguji hipotesis penelitian, kuesioner disebarkan secara langsung kepada nasabah Bank BPD Bali terutama di daerah-daerah operasionalnya dan juga kelompok masyarakat yang mengetahui program CSR Bank BPD Bali. Penelitian ini menggunakan accidental sampling 
dalam pengambilan sampelnya, dengan cara menghentikan beberapa orang secara spontan, kemudian ditanyakan kesediaannya untuk mengisi kuesioner penelitian. Sebanyak 100 kuesioner terisi dengan benar digunakan dalam analisis. Kuesioner disusun dengan menggunakan skala 1 sampai dengan 10, dimana 1 menunjukkan sangat tidak setuju dan 10 menunjukkan sangat setuju.

Data kemudian dianalisis dengan menggunakan structural equation modeling (SEM), dimana variabel yang digunakan adalah variabel eksogen, indikator (variabel terukur/measured variablelobserved variable) dan variabel endogen (Ferdinand, 2014). Ukuran sampel yang harus dipenuhi dalam pemodelan SEM adalah minimum berjumlah 100. Jumlah sampel adalah jumlah indikator dikalikan 5 sampai 10 (Ferdinand, 2014). Penelitian ini menggunakan 20 indikator, sehingga sampel penelitian yang baik berkisar antara 100 hingga 200. Dengan demikian, penelitian ini telah memenuhi kriteria kecukupan jumlah sampel.

\section{HASIL DAN PEMBAHASAN}

Sebelum dilakukan pengujian hipotesis dan model penelitian, terlebih dahulu dilakukan uji validitas dan reliabilitas terhadap instrumen penelitian. Sebanyak 30 kuesioner dikumpulkan secara langsung dalam pilot test atau uji pendahuluan, untuk kemudian dilakukan proses tabulasi dan olah data menggunakan program SPSS versi 22. Hasil uji validitas dan reliabilitas membuktikan bahwa seluruh item pertanyaan atau indikator dalam masing-masing variabel adalah valid (seluruh item pertanyaan memiliki rhitung > rtabel) dan reliabel/handal (Cronbach's $>0,60$ ) untuk digunakan pada analisis lanjutan.

Kemudian, uji normalitas juga dilakukan terhadap sebaran data untuk masing-masing indikator penelitian. Tidak ada indikator yang memiliki c.r. untuk skweness diatas $\pm 3,00$. Ini berarti sebaran data untuk semua indikator adalah normal ditinjau dari kemencengan. Dilihat dari kurtosis (keruncingan) tidak ada indikator yang memiliki c.r. di atas $>3,00$. Ini berarti, dilihat dari kurtosis (keruncingan) dapat dikatakan bahwa penyebaran data untuk semua indikator adalah menyebar normal (tidak runcing). Dengan demikian ditinjau dari normalitas data, dapat dinyatakan data untuk seluruh indikator menyebar normal, sehingga data dapat dianalisis lebih lanjut.

Analisis faktor konfirmatori kemudian dilakukan untuk menguji unidimensionalitas dari dimensi-dimensi yang menjelaskan variabel-variabel laten, apakah seluruh indikator merupakan pembentuk variabel latennya. Analisis faktor konfirmatori ini juga dimaksudkan untuk menganalisis tingkat validitas dari data yang digunakan. Artinya, apakah indikator yang digunakan memiliki kebermaknaan yang cukup untuk mendefinisikan variabel laten yang dibentuk. Menurut Ferdinand (2014, p. 24), sebuah indikator signifikan mendefinisikan variabel laten jika memiliki koefisien lambda/standardized regression weight $(\lambda) \geq 0,5$ dan nilai kritis (C.R.) $\geq 2,00$ serta nilai probabilitas $(\mathrm{P})<0,05$. Berdasarkan hasil analisis faktor konfirmatori terhadap seluruh indikator, diketahui bahwa standardized regression weight $(\lambda)$ untuk seluruh indikator lebih besar dari 0,5, koefisien C.R. lebih besar dari 2,00 dan nilai probabilitas seluruhnya lebih kecil dari 0,05 (***). Dengan demikian dapat dikatakan bahwa seluruh indikator mampu mendefinisikan variabel latennya dengan baik.

Sebelum dilakukan pengujian hipotesis penelitian, terlebih dahulu dilakukan uji kelayakan model. Seluruh Goodness of fit Index model penelitian ini telah memenuhi kriteria model yang 
baik (Chi-square $\left(\mathrm{X}^{2}\right)$ : 7,140; Relative Chi-square ( $\left.\mathrm{X}^{2} / \mathrm{df}\right)$ : 1,785; Probability: 0,178; RMSEA: 0,04; GFI: 0,926; AGFI: 0,981; TLI: 0,921; CFI: 0,956).

Gambar 1 menampilkan model penelitian hasil analisis SEM yang telah memenuhi kriteria model yang baik/fit. Sementara rangkuman hasil uji hubungan antar variabel ditampilkan dalam Tabel 1.

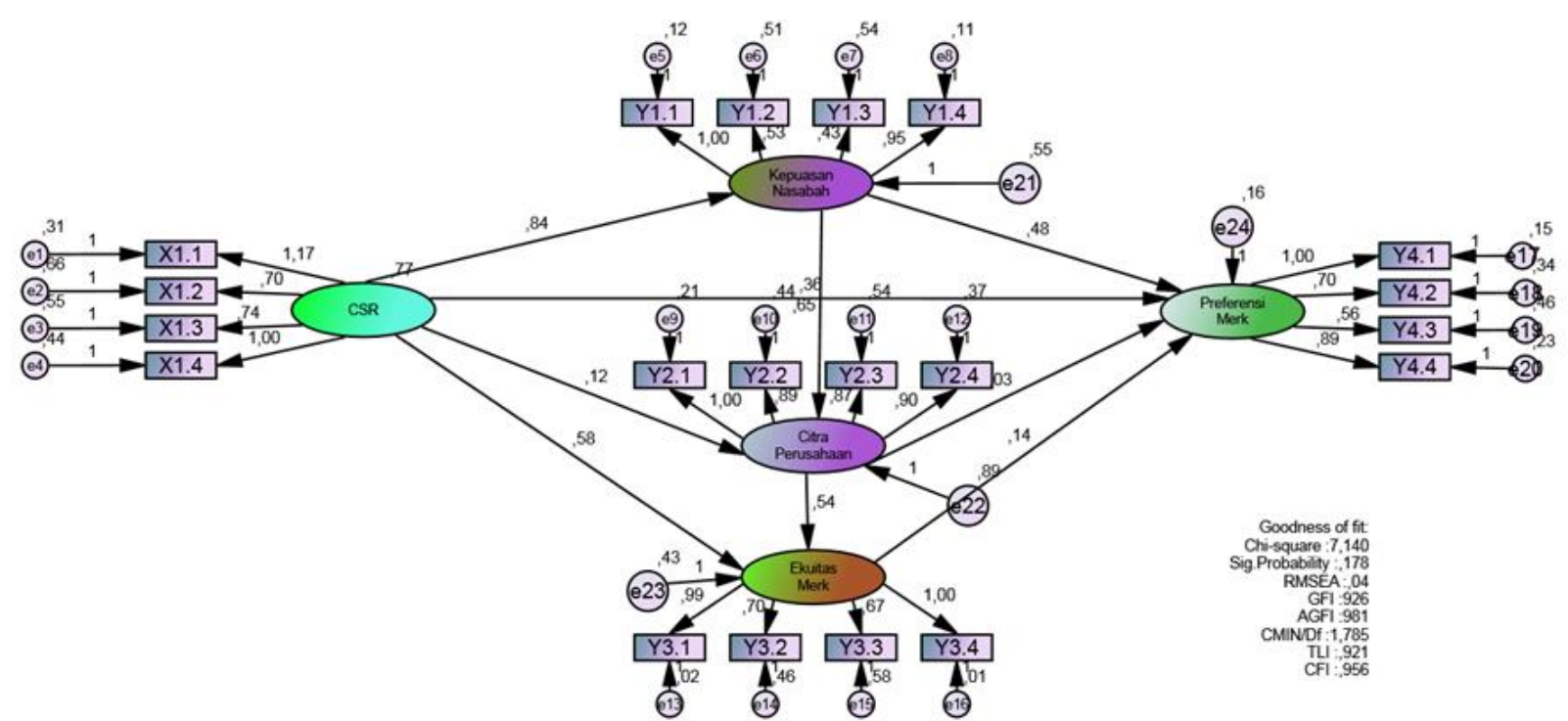

Gambar 1. Model Pengaruh Corporate Social Responsibility, Kepuasan Nasabah, Citra Perusahaan, dan Ekuitas Merek terhadap Preferensi Merek Bank BPD Bali

Tabel 1. Hasil Uji Hubungan Antar Variabel

\begin{tabular}{|c|c|c|c|c|c|c|c|c|}
\hline & & & $\begin{array}{r}\text { Std. } \\
\text { Estimate }\end{array}$ & Estimate & S.E. & C.R. & $\mathrm{P}$ & Label \\
\hline Kepuasan_Nasabah & $\begin{array}{l}<-- \\
\end{array}$ & CSR &, 704 & 836 & 121 & 6,923 & $* * *$ & Signifikan \\
\hline Citra_Perusahaan & $<--$ & CSR & ,084 & ,116 & ,189 & 2,215 & ,038 & Signifikan \\
\hline Citra_Perusahaan & $<---$ & Kepuasan_Nasabah & ,564 & ,655 & ,155 & 4,226 & $* * *$ & Signifikan \\
\hline Ekuitas_Merk & $<---$ & CSR & ,426 &, 584 & 111 & 5,259 & $* * *$ & Signifikan \\
\hline Ekuitas_Merk & $<--$ & Citra_Perusahaan & 546 & ,542 & ,074 & 7,301 & $* * *$ & Signifikan \\
\hline Preferensi_Merk & $<---$ & CSR & ,318 & ,361 & ,121 & 2,983 & ,003 & Signifikan \\
\hline Preferensi_Merk & $<---$ & Kepuasan_Nasabah & ,501 & ,479 & ,092 & 5,209 & $* * *$ & Signifikan \\
\hline Preferensi_Merk & $<---$ & Citra_Perusahaan & 040 & 033 & ,078 & 2,425 & 032 & Signifikan \\
\hline Preferensi_Merk & $<--$ & Ekuitas_Merk & 167 & ,138 & ,088 & 2,580 & ,028 & Signifikan \\
\hline
\end{tabular}

Sebagaimana terlihat pada Tabel 1, seluruh hubungan antar variabel memiliki nilai C.R. > 2,000 dan probability $<0,05$, dengan demikian hubungan antar variabel yang dihipotesiskan seluruhnya signifikan.

Untuk menganalisis besarnya kontribusi variabel-variabel eksogen dalam menjelaskan variabel endogen, digunakan nilai square multiple correlation. Menurut Ferdinand (2014, p. 114), nilai square multiple correlation identik dengan $\mathrm{R}^{2}$ pada SPSS. Nilai square multiple correlation untuk variabel kepuasan nasabah sebesar 0,495, dapat dinyatakan bahwa variabel kepuasan nasabah dijelaskan oleh variabel CSR sebesar 49,5\%. Variabel citra perusahaan dijelaskan oleh CSR dan kepuasan nasabah sebesar 39,1\%; ekuitas merek dijelaskan oleh CSR dan citra perusahaan sebesar 70,3; preferensi merek dijelaskan oleh CSR, kepuasan nasabah, citra perusahaan dan ekuitas merek sebesar $83,5 \%$. Secara umum dapat dikatakan bahwa model penelitian ini sudah baik, mengingat variabel endogen mampu dijelaskan sebanyak $83,5 \%$ oleh 
variabel-variabel eksogennya.

\section{Pembahasan atas Hasil Penelitian}

Pengujian secara empiris menunjukkan bahwa pengaruh variabel CSR terhadap kepuasan nasabah adalah signifikan, dengan demikian Hipotesis 1 penelitian ini diterima, semakin baik CSR maka semakin tinggi tingkat kepuasan nasabah Bank BPD Bali. Temuan penelitian ini bersesuaian dengan Tan dan Komaran (2006), yang menemukan bahwa kegiatan kedermawanan yang dilakukan oleh perusahaan dapat berpengaruh secara tidak langsung terhadap permintaan konsumen melalui tingkat kepuasan dan ingatan pelanggan yang tinggi terhadap suatu barang ataupun jasa. Praktik CSR membuat perusahaan lebih memahami dan dapat meningkatkan pengetahuan khusus atas pelanggannya, hal ini akan berdampak pada kepuasan pelanggan (McWilliams et al., 2006). Athanassopoulos (2000) mengatakan bahwa nilai CSR berdampak terhadap kepuasan pelanggan.

Pengujian secara empiris menunjukkan bahwa pengaruh variabel CSR terhadap citra perusahaan adalah signifikan, dengan demikian Hipotesis 2 penelitian ini diterima, semakin baik CSR maka semakin baik citra Bank BPD Bali. Penelitian ini memberikan bukti empiris dan dukungan terhadap beberapa penelitian sebelumnya terkait pengaruh CSR terhadap citra perusahaan. Yulianita (2008) berpendapat bahwa kegiatan CSR dilakukan untuk dapat merespon keadaan sosial yang terjadi di lingkungan sekitar yang tidak hanya dinikmati atau dimanfaatkan oleh lingkungan sekitar yang menjadi sasaran saja tetapi juga perusahaan tersebut akan menerima manfaaat atas kegiatan yang mereka lakukan tersebut khususnya dalam penciptaan, peningkatan, dan pemeliharaan citra perusahaan di mata masyarakat. Penelitian oleh Yenti (2013) menunjukan bahwa bantuan dana sosial bergulir dari perusahaan kepada masyarakat di sekitar lingkungan perusahaan memiliki pengaruh pada citra perusahaan. Penelitian yang dilakukan oleh Husni Falah Wijaya (2015) menunjukkan hasil yang serupa, yaitu aspek sosial memiliki pengaruh pada citra perusahaan, hal ini menunjukan bahwa dukungan aktif yang diberikan oleh perusahaan dalam kegiatan sosial memberikan pengaruh positif pada masyarakat di lingkungan sekitar perusahaan, oleh karena itu masyarakat memiliki opini positif pada citra perusahaan.

Pengujian secara empiris menunjukkan bahwa pengaruh variabel CSR terhadap ekuitas merek adalah signifikan, dengan demikian Hipotesis 3 penelitian ini diterima, semakin baik CSR maka semakin tinggi ekuitas merek Bank BPD Bali. Kegiatan CSR yang dilaksanakan oleh suatu perusahaan dapat menimbulkan kesetiaan merek/brand loyalty, yang merupakan indikator dari ekuitas merek. Brand loyalty terbentuk dari kesan positif terhadap suatu produk yang menimbulkan ikatan emosional yang kuat (Ariningsih, 2009). Beberapa penelitian terdahulu menemukan bahwa terdapat hubungan antara CSR dengan ekuitas merek. CSR yang dilakukan dengan baik akan berpengaruh positif terhadap reputasi perusahaan. Namun membutuhkan waktu yang panjang agar terbentuk reputasi positif perusahaan dan terbangun ekuitas merek yang diharapkan dapat menambah kepuasan dan meningkatkan loyalitas merek (Ariningsih, 2009). Menurut Handayani (2012), semakin banyak kegiatan atau interaksi CSR yang dilakukan oleh suatu perusahaan, maka akan semakin tinggi tingkat reputasi perusahaan dan ekuitas merek di mata konsumen dan para stakeholder-nya.

Pengujian secara empiris menunjukkan bahwa pengaruh variabel CSR terhadap preferensi merek adalah signifikan, dengan demikian Hipotesis 4 penelitian ini diterima, semakin baik CSR maka semakin tinggi preferensi merek Bank BPD Bali. Baskentli, Sen, Du dan Bhattacharya (2019) meneliti reaksi konsumen terhadap CSR. Penelitian mereka mengindikasikan bahwa CSR secara langsung memberikan pengaruh pada niat konsumen untuk membeli produk atau menggunakan 
jasa-jasa perusahaan tersebut. Penelitian Yenti (2013) mengindikasikan bahwa CSR berpengaruh signifikan terhadap preferensi merek perusahaan. Polonsky dan Jevons (2006) berpendapat bahwa perusahaan yang memahami bagaimana melakukan CSR dalam meningkatkan preferensi merek mereka akan lebih unggul dari para pesaingnya. Pelaksanaan CSR dapat dikemas untuk mengupayakan preferensi positif dari konsumen atau sebagai alat promosi perusahaan yang sangat efektif. Perusahaan yang memahami bagaimana melakukan CSR dalam meningkatkan preferensi merek mereka akan lebih unggul daripada para pesaingnya.

Pengujian secara empiris menunjukkan bahwa pengaruh variabel kepuasan nasabah terhadap citra perusahaan adalah signifikan, dengan demikian Hipotesis 5 penelitian ini diterima, semakin tinggi kepuasan nasabah maka semakin baik citra Bank BPD Bali. Kepuasan pelanggan terhadap pengalaman layanan memperkuat perilaku seseorang melalui Word Of Mouth (WOM) untuk kemudian mempengaruhi citra suatu perusahaan (Avinandan Mukherjee, 2003). Baik buruknya kualitas layanan tidak hanya berdasarkan persepsi terhadap penyedia layanan, tetapi juga berdasarkan persepsi nasabahnya (Ravichandran et al., 2010). Citra perusahaan dinilai penting bagi setiap perusahaan karena merupakan keseluruhan kesan yang terbentuk di benak masyarakat tentang perusahaan. Perusahaan diharapkan mengkomunikasikan secara jelas tentang bagaimana perusahaan memenuhi keinginan dan kebutuhan pasar yang berorientasi pada pelanggan sehingga dapat mengarahkan masyarakat dalam mencitrakan perusahaan secara positif.

Pengujian secara empiris menunjukkan bahwa pengaruh variabel citra perusahaan terhadap ekuitas merek adalah signifikan, dengan demikian Hipotesis 6 penelitian ini diterima, semakin baik citra perusahaan maka semakin tinggi ekuitas merek Bank BPD Bali. Penelitian ini senada dengan beberapa penelitian terdahulu yang meneliti hubungan citra perusahaan dengan ekuitas merek, antara lain Handayani (2012) mengindikasikan bahwa ekuitas merek dipengaruhi secara positif dan signifikan oleh reputasi perusahaan. Di dalam persaingan bisnis yang semakin ketat ini, memiliki keunggulan kompetitif merupakan hal yang penting bagi perusahaan. Perusahaan perlu melakukan upaya untuk meningkatkan reputasinya sebagai salah satu keunggulan kompetitif, yang pada akhirnya dapat meningkatkan penjualan (Kotler \& Lee, 2005).

Pengujian secara empiris menunjukkan bahwa pengaruh kepuasan nasabah terhadap preferensi merek adalah signifikan, dengan demikian Hipotesis 7 penelitian ini diterima, semakin tinggi kepuasan nasabah maka semakin tinggi pula preferensi merek Bank BPD Bali. Kepuasan pelanggan berhubungan erat dengan loyalitas pelanggan, dimana pelanggan yang terpuaskan akan menjadi pelanggan yang loyal, kemudian pelanggan yang loyal tersebut secara tidak langsung akan menjadi tenaga pemasaran bagi perusahaan tersebut yaitu dengan cara memberikan rekomendasi dan informasi positif kepada calon pelanggan lain (Mowen, J.C., and Minor, 1998). Schiffman dan Kanuk (2004) menyatakan bahwa tingkat kepuasan konsumen merupakan salah satu faktor yang mempengaruhi derajat loyalitas atau preferensi merek konsumen.

Pengujian secara empiris menunjukkan bahwa pengaruh citra perusahaan terhadap preferensi merek adalah signifikan, dengan demikian Hipotesis 8 penelitian ini diterima, semakin baik citra perusahaan maka semakin tinggi pula preferensi merek Bank BPD Bali. Samuel dan Foedjiawati (2005) mengemukakan bahwa terbentuknya citra positif sebagai akibat pelaksanaan program CSR oleh suatu perusahaan akan membawa dampak pada keberhasilan kegiatan bisnis dan pemasaran perusahaan. Dalam jangka panjang, pencitraan positif ini akan membawa banyak manfaat bagi perusahaan pelaku CSR, baik pada saat perusahaan sedang mengalami masa kejayaan maupun pada saat menghadapi berbagai macam krisis. Beberapa manfaat yang dapat 
diperoleh perusahaan yang memiliki citra yang baik antara lain: menjadi perisai di saat keadaan krisis, meningkatkan daya saing untuk jangka menengah dan jangka panjang, penghematan biaya operasional dan meningkatkan efektifitas strategi pemasaran, yang pada akhirnya akan meningkatkan preferensi atau kesetiaan terhadap merek perusahaan.

Pengujian secara empiris menunjukkan bahwa pengaruh ekuitas merek terhadap preferensi merek adalah signifikan, dengan demikian Hipotesis 9 penelitian ini diterima, semakin tinggi ekuitas merek maka semakin tinggi preferensi merek bank BPD Bali. Prasad dan Dev (2000) menyatakan bahwa ekuitas merek yang tinggi berhubungan dengan kepuasan pelanggan yang tinggi, preferensi merek, dan loyalitas. Hal ini didukung pula oleh penelitian Rofiq, Suryadi dan Faidah (2009) yang menyatakan bahwa semakin kuat ekuitas merek suatu produk, semakin kuat daya tariknya di mata konsumen untuk termotivasi memilih produk tersebut.

\section{KESIMPULAN DAN SARAN}

Penelitian ini membuktikan bahwa terdapat hubungan positif signifikan antara: (1) CSR dengan tingkat kepuasan nasabah; (2) CSR dengan citra perusahaan; (3) CSR dengan ekuitas merek; (4) CSR dengan preferensi merek; (5) Tingkat kepuasan nasabah dengan citra perusahaan; (6) Citra perusahaan dengan ekuitas merek; (7) Kepuasan nasabah dengan preferensi merek; (8) Citra perusahaan dengan preferensi merek; (9) Ekuitas merek dengan preferensi merek. Model penelitian ini telah memenuhi seluruh kriteria goodness of fit index sebagai model yang baik. Selain itu, variabel-variabel eksogen dalam penelitian ini mampu menjelaskan sebanyak 83,5\% dari variasi variabel endogen. Hal ini dapat juga menjadi indikasi model yang baik. Penelitian ini memberikan bukti empiris bahwa praktik CSR memiliki peran yang penting dalam upaya meningkatkan kepuasan nasabah, citra perusahaan, ekuitas merek dan preferensi merek.

Berdasarkan hasil pengujian indikator penelitian, terdapat beberapa indikator yang memperoleh skor rendah dari responden, yaitu: penerimaan masyarakat akan keberadaan bank, rekomendasi, asosiasi/diferensiasi merek, dan pilihan merek. Dengan demikian dapat disarankan kepada pihak manajemen Bank BPD Bali untuk memperbanyak unit pelayanannya sehingga mudah dijangkau oleh masyarakat, meningkatkan kualitas pelayanan sehingga timbul keinginan untuk merekomendasikan Bank BPD Bali, menciptakan produk-produk baru yang khas, unik dan berbeda dengan produk-produk bank pesaing, dan meningkatkan intensitas promosi produk dan aktivitas penguatan merek Bank BPD Bali. Sosialisasi atas praktik CSR juga masih perlu ditingkatkan untuk mengoptimalkan manfaat CSR bagi peningkatan reputasi perusahaan.

Penelitian ini menawarkan model yang menjelaskan hubungan antara CSR, kepuasan nasabah, citra perusahaan, ekuitas merek dan preferensi merek. Model penelitian ini telah diuji secara empiris. Namun untuk dapat memastikan kehandalan model ini, masih dibutuhkan penelitian lanjutan yang menggunakan data bersumber dari nasabah beberapa bank. Penelitian ini hanya berfokus pada nasabah satu bank saja, yaitu Bank BPD Bali.

\section{REFERENSI}

Ariningsih, E. P. (2009). Pengaruh Penerapan Program Corporate Social Responsibility (CSR) pada Pembentukan Brand Equity. Segmen-Manajemen, 1, 1-24.

Athanassopoulos, A. D. (2000). Customer Satisfaction Cues to Support Market Segmentation and Explain Switching Behavior. Journal of Business Research, 47(3), 191-207.

Baskentli, S., Sen, S., Du, S., \& Bhattacharya, C. B. (2019). Consumer reactions to corporate social responsibility: The role of CSR domains. Journal of Business Research, 95, 502513. 
Cavusgil., S. Tamer., Knight., Gary., and Riesenberger., J. R. (2014). International Business, The New Realities (Third). Pearson Education Limited.

Cronin, Joseph JR., Brady, Michael K., and Hult, T. M. (2000). Assesing The Effect Of Quality, Value, and Customer Satisfaction On Consumer Behavioral Intentions In Service Environment. Journal Of Retailing, 76(2), 193-218.

Ferdinand, A. (2014). Structural Equation Modeling Dalam Penelitian Manajemen (5th ed.). Badan Penerbit Undip.

Handayani, E. N. (2012). Analisis Program Corporate Social Responsibility (CSR) dalam Membangun Corporate Reputation, Brand Equity, dan Social Equity Brand (Studi Kasus pada Merek Lifebuoy dari PT Unilever) Universitas Indonesia, Jakarta. University of Indonesia.

Hassan, Z., and Nareeman, A. (2013). Impact of CSR Practices on Customer Satisfaction and Retention: An Empirical Study on Foreign MNCs in Malaysia. International Journal of Accounting, and Business Management (IJABM), 1(1), 63-81.

Husni Falah Wijaya. (2015). Pengaruh Corporate Social Responsibility (CSR) terhadap Citra Perusahaan (Survei pada Masyarakat Penerima Program CSR PT. Pindad (Persero) di Kelurahan Sedayu, Kecamatan Turen, Kabupaten Malang). Jurnal Administrasi Bisnis, 19(1).

Kiroyan, N. (2009). CSR Compliance and Business Opportunities Materi presentasi.

Kotler, P., \& Lee, N. (2005). Corporate Social Responsibility: Doing the Most Good for Your Company and Your Cause. John Wiley \& Sons, Inc.

McWilliams, A., Siegel, D. S., \& Patrick M. Wright. (2006). Corporate Social Responsibility: Strategic Implications. Journal of Management Studies, 43(1), 1-18.

Mowen, J.C.,and Minor, M. (1998). Consumer Behavior (5th Ed.). Prentice Hall, Inc.

Mukherjee, A. (2003). Franchaise Management: A Model Of Service Quality. International Journal Of Quality and Reliability Management, 20(3), 325-344.

Mukherjee, Avinandan. (2003). Franchaise Management: A Model Of Service Quality. International Journal Of Quality and Reliability Management, 20(3), 325-344.

Naik, C.N. Krishna., Gantasala, S.B., and Prabhakar, G. V. (2010). Service Quality and its Effects on Customer Satisfaction in Retail. Europan Journal of Social Science, 16(2), 230-242.

Polonsky, M. J., \& Jevons, C. (2006). Understanding Issue Complexity When Building a Socially Responsible Brand. European Business Review, 18(5), 340-349.

Prasad, K., \& Dev, C. S. (2000). Managing Hotel Brand Equity: A Customer Centric Framework for Assessing Performance. Cornell Hotel and Restaurant Administration Quarterly, 41(3), 22-31. https://scholarship.sha.cornell.edu/articles/765/

Ravichandran, K., Mani, B. ., Kumar, S. A., \& Prabhakaran, S. (2010). Influence of Service Quality on Customers Satisfaction, Application of Servqual Mode. International Journal Of Business and Management, 5(4), 117-124.

Rofiq, A., Suryadi, N., \& Faidah, N. N. (2009). Peranan Ekuitas Merek Terhadap Loyalitas Pelanggan Pada Industri Telepon Seluler. The 3rd National Conference on Management Research.

Samuel, H., \& Foedjiawati. (2005). Pengaruh Kepuasan Konsumen Terhadap Kesetian Merek (Studi Kasus Restoran The Prime Steak \& Ribs Surabaya). Jurnal Manajemen Dan Wirausaha, 7(1), 74-82.

Schiffman, L.G., and Kanuk, L. L. (2004). Perilaku Konsumen, Edisi Ketujuh. Indeks Group Gramedia.

Shaikh, M., Ali, C. U. A., \& Khan Naved Ur Rehman. (2011). Impact Of Service Quality on Costumer Statisfaction: Evidence from the Resturant Industry in Pakistan. Management 
\& Marketing, 9(2), 344-355.

Suharto, E. (2009). Pekerjaan Sosial di Dunia Industri: Memperkuat CSR (Corporate Social Responsibility). Alfabeta.

TAN, G. Y. W., \& KOMARAN, R. V. (2006). Perceptions of Corporate Social Responsibility: An Empirical Study in Singapore; Strategic Management Policy. https://ink.library.smu.edu.sg/cgi/viewcontent.cgi?article=3845\&context=1kcsb_research

Yenti, A. (2013). Pengaruh Penerapan Program Corporate Social Responsibility Terhadap Citra Perusahaan. Jurnal Manajemen Universitas Padang, 2(1), 20-32.

Yulianita, N. (2008). Corporate Social Responsibility (CSR) sebagai Aktivitas Social Marketing Public Relations. Mediator Jurnal Komunikasi, 9(1), 11-31. 